\title{
MyD88 adaptor-like (Mal) regulates intestinal homeostasis and colitis-associated colorectal cancer in mice
}

\author{
Gabriella Aviello, ${ }^{1}$ Sinéad C. Corr, ${ }^{1}$ Daniel G. W. Johnston, ${ }^{1}$ Luke A. J. O’Neill, ${ }^{1}$ \\ and Padraic G. Fallon ${ }^{1,2,3}$ \\ ${ }^{1}$ Trinity Biomedical Sciences Institute, Trinity College Dublin, Dublin, Ireland; ${ }^{2}$ National Children's Research Centre, Our \\ Lady's Children's Hospital, Crumlin, Ireland; and 'Institute of Molecular Medicine, St James's Hospital, Dublin, Ireland
}

Submitted 20 November 2013; accepted in final form 2 March 2014

Aviello G, Corr SC, Johnston DG, O’Neill LA, Fallon PG. MyD88 adaptor-like (Mal) regulates intestinal homeostasis and colitis-associated colorectal cancer in mice. Am J Physiol Gastrointest Liver Physiol 306: G769-G778, 2014. First published March 6, 2014; doi:10.1152/ajpgi.00399.2013.-Toll-like receptors (TLRs) play a central role in the recognition and response to microbial pathogens and in the maintenance and function of the epithelial barrier integrity in the gut. The protein MyD88 adaptor-like (Mal/TIRAP) serves as a bridge between TLR2/TLR4- and MyD88-mediated signaling to orchestrate downstream inflammatory responses. Whereas MyD88 has an essential function in the maintenance of intestinal homeostasis, a role for Mal in this context is less well described. Colitis was induced in wild-type (WT) and Mal-deficient $\left(\mathrm{Mal}^{-{ }^{-}}\right)$mice by administration of dextran sodium sulfate (DSS). Colitis-associated cancer was induced by DSS and azoxymethane (AOM) treatment. Chimeric mice were generated by total body gamma irradiation followed by transplantation of bone marrow cells. In the DSS model of colon epithelial injury, $\mathrm{Mal}^{-/-}$mice developed increased inflammation and severity of colitis relative to WT mice. $\mathrm{Mal}^{-1-}$ mice demonstrated the presence of inflammatory cell infiltrates, increased crypt proliferation, and presence of neoformations. Furthermore, in the AOM/DSS model, $\mathrm{Mal}^{-\prime-}$ mice had greater incidence of tumors. $\mathrm{Mal}^{-/-}$and WT bone marrow chimeras demonstrated that nonhematopoietic cell expression of Mal had an important protective role in the control of intestinal inflammation and inflammation-associated cancer. Mal is essential for the maintenance of intestinal homeostasis and expression of Mal in nonhematopoietic cells prevents chronic intestinal inflammation that may predispose to colon neoplasia.

Goll-like receptors; MyD88; inflammation; colon cancer; bone marrow chimera

INFLAMMATORY BOWEL DISEASES (IBD), consisting of Crohn's disease (CD) and ulcerative colitis (UC), are idiopathic, chronic and relapsing disorders characterized by inflammation of the gastrointestinal tract in genetically susceptible individuals exposed to environmental risk factors (35). The incidence and prevalence of IBD are highest in westernized society with a long-term impact on health-associated costs (31). The etiology of IBD has been extensively studied in the past few years (31); however, disease pathogenesis still remains complex and not fully understood. In IBD patients, the physiological mechanisms regulating the host's immunological tolerance to the continuous exposure to resident gut microbiota are altered (49). The abnormal sensing of commensal microorganisms by the gut innate immune system leads to a chronic inflammatory

\footnotetext{
Address for reprint requests and other correspondence: P. G. Fallon, School of Medicine, Trinity Biomedical Sciences Institute, Trinity College Dublin, Dublin 2, Ireland (e-mail: pfallon@tcd.ie).
}

state (40) that is considered a promoter of colon carcinogenesis $(8,28)$.

Toll-like receptors (TLRs) are a family of single-pass transmembrane proteins that crucially mediate innate immune responses to microbial stimuli such as bacterial lipids and nonself nucleic acids (45). A common adaptor protein for most TLRs is the myeloid differentiation factor 88 (MyD88) that mediates specific protein-protein interactions essential to drive the formation of TLR signalosome and ultimately promote the nuclear translocation of NF- $\mathrm{B}$ (27). Although TLRs can directly engage MyD88, TLR4 (18, 24) and TLR2 (23, 50) require a second adapter, the TIR domain-containing adapter protein (TIRAP) (24), also termed MyD88 adaptor-like (Mal; herein after referred as Mal only) (18). Similar to MyD88, Mal functions as a bridge between TLR2 and TLR4 and orchestrates downstream inflammatory responses (30). The role of MyD88 in regulating NF- $\mathrm{KB}$ activation and the transcription of enterocyte survival factors has been uncovered by a number of studies indicating a divergent role of MyD88 in cancer development (38). In genetic animal models of colon cancer $M y d 88^{-1-}$ mice are protected from adenoma growth and progression (36), and the high expression of MyD88 is associated with poor prognosis in colorectal cancer patients (47). On the other hand, MyD88-deficient mice are highly susceptible to the development of colonic inflammation $(2,37)$ and cancer (39), with innate MyD88 rather than an epithelial cell MyD88 signal having a pivotal role in the development of chronic intestinal inflammation (5).

It has been recently shown that Mal-deficient mice are more susceptible to develop disease after oral infection with Salmonella Typhimurium, showing a key role for Mal in the maintenance of intestinal epithelial barrier function. This was indicated to be through the activation of protein kinase $\mathrm{C}$ and expression of tight junction proteins (13). Although a number of experimental models have shown a crucial role for MyD88 in the development of cancer $(14,32,37)$, the biological significance of Mal in epithelial homeostasis and colitis still needs to be fully understood (25). Thus in this study we examined the function of Mal in colon physiopathology by means of preclinical models of colitis and colitis-associated carcinogenesis (CAC).

\section{MATERIALS AND METHODS}

Mice. $\mathrm{Mal}^{-1-}$, Ptprc $^{b}\left(\mathrm{CD} 45.2^{+}\right)$, and Ptprc ${ }^{a}\left(\mathrm{CD} 45.1^{+}\right)$wild types (WT), all on a C57BL/6 background, were obtained from Jackson Laboratories (Bar Harbor, ME) and bred in-house. Mice were housed in a specific pathogen-free facility in individually ventilated and filtered cages under positive pressure. All animal experiments were performed in compliance with Irish Department of Health and 
Children regulations and approved by the Trinity College Dublin's BioResources ethical review board.

DSS-induced colitis. Colitis was induced in age- and sex-matched WT and $\mathrm{Mal}^{-1-}$ mice as described previously (41). In brief, mice were treated with $2.5 \%$ (wt/vol) dextran sodium sulfate (DSS, 36-50 $\mathrm{kDa}$; MP Biomedicals) in drinking water for 5 days followed by normal water for 5 days. Mice were checked daily for morbidity, and body weight was recorded. The disease activity index (DAI) was calculated daily for each mouse as described (41). The maximum DAI score was 12 based on assigning a 1-4 scoring system for each parameter: score 0 , no weight loss, normal stool and no blood; score 1, 1-3\% weight loss; score 2, 3-6\% weight loss, loose stool (a loose stool was defined as the formation of a stool that readily becomes paste upon handling) and blood visible in stool; score 3, 6-9\% weight loss; and score $4,>9 \%$ weight loss, diarrhea, and gross bleeding.

AOM/DSS-induced CAC. Inflammation-associated colon cancer was induced by the coadministration of azoxymethane (AOM) and DSS (33). For the induction of colon tumors, female WT and $\mathrm{Mal}^{-1-}$ mice were injected intraperitoneally once with $10 \mathrm{mg} / \mathrm{kg}$ AOM (Sigma-Aldrich) followed by $2.5 \%$ DSS in drinking water for 5 days (week 1). This cycle was repeated twice (at week 4 and week 7) and mice were euthanized at week 10 (for protocol see Fig. 3A). Mice were monitored daily for morbidity and body weight was recorded weekly. DAI was determined as above, at the termination of the study.

Generation of bone marrow chimeras. Chimeric mice were generated by total body gamma irradiation followed by transfer of bone marrow cells (17). Briefly, CD45.1 ${ }^{+} \mathrm{WT}$ and CD $45.2^{+} \mathrm{Mal}^{-1-}$ recipient mice were lethally irradiated with a dose of 9 Gy (in 2 divided doses, $3 \mathrm{~h}$ apart) and then injected intravenously with $1 \times 10^{7}$ cells/mouse from CD $45.1^{+}$WT or CD 45.2 $2^{+} \mathrm{Mal}^{-1-}$ mice (Fig. 4A). We obtained the following experimental groups: WT $>$ WT, $\mathrm{Mal}^{-\prime-}>$ $\mathrm{WT}, \mathrm{WT}>\mathrm{Mal}^{-/-}$and $\mathrm{Mal}^{-/-}>\mathrm{Mal}^{-1-}$ (donor $>$ recipient). The level of cell engraftment was assessed in the blood by measuring the cell surface expression of CD45.1 and CD45.2 by flow cytometry after $8 \mathrm{wk}$. Under our standardized protocol, chimeric mice routinely show a level of reconstitution $>98 \%$ (Fig. $4 B$ ).

Macroscopic evaluation of tumors. The formation of tumors in the colon was evaluated as previously described (7). Colons were excised, fixed flat in $10 \%$ buffered formalin for $24 \mathrm{~h}$ and then stained with $0.2 \%$ methylene blue (MB). The total number of tumors per mouse was scored stereomicroscopically blind and the size of each tumor mass was measured with a micrometer.

Histology. At autopsy, $\sim 1 \mathrm{~cm}$ of the distal colon was removed and fixed in $10 \%$ buffered formalin. Sections $(5 \mu \mathrm{m})$ were stained with hematoxylin and eosin. Sections were graded blind by using a cumulative score ranging from 0 to $3-4$ (41). An arbitrary maximum combined score of 10 was determined from the severity of inflammatory cell infiltration (score 0 , none; score 1, slight-dispersed cell infiltrate; score 2, moderate-increased cell infiltrates forming occasional cell foci; score 3 , severe-large areas of cell infiltrates causing loss of tissue architecture), extent of injury (score 0 , none; score 1 , mucosal; score 2, mucosal and submucosal; score 3, transmural), and crypt damage (score 0 , none; score 1 , basal 1/3 damaged; score 2, basal 2/3 damaged; score 3, only surface epithelium intact; score 4, loss of entire crypt and epithelium).

Immunohistochemistry and TUNEL assay. Colon epithelial cell proliferation was analyzed by Ki67 immunostaining, whereas cell death was visualized by TdT-mediated dUTP-X nick-end labeling (TUNEL). For immunohistochemistry, paraffin-embedded sections were hydrated and blocked for nonspecific background staining with $10 \%$ normal goat serum (DakoCytomation), incubated overnight with rabbit polyclonal anti-Ki67 antibody (Abcam), visualized by EnVision Detection System (DakoCytomation), and counterstained with Mayer's hematoxylin (Sigma-Aldrich). TUNEL assay was performed on paraffin-embedded sections with a commercial kit (In Situ Cell Death Detection kit, Roche, Germany) according to manufacturer's instructions. At $\times 40$ magnification one high-power field (HPF) con- tains approximately one villus. The first six well-defined crypts per HPF (5-6 crypts/section and 2-3 sections/mouse) were selected and Ki67- or TUNEL-positive cells were counted. Sections were imaged by a Leica microscope (Leica DM 3000 LED) equipped with Leica DFC495 camera (Leica Microsystem).

Colon MPO and cytokines and SAA levels. Colons were homogenized in a buffer containing $1 \times$ PBS, $2 \%$ fetal bovine serum, and $0.5 \%$ cetyltrimethylammonium bromide. Myeloperoxidase (MPO) enzymatic activity was detected by using $O$-phenylenediamine as substrate and data interpolated from a MPO (Sigma-Aldrich) standard curve. IL-1 $\beta$, IL-6, IL-17A, and IL-17F in colon homogenates was detected by ELISA kit (R\&D Systems), according to manufacturer's instructions. Serum amyloid A (SAA) levels were measured in sera recovered at termination of the study by use of a commercial kit (Life Diagnostics), as described (6).

Flow cytometry. Reconstitution of chimeras was analyzed by flow cytometry on blood recovered from mice $6 \mathrm{wk}$ after body irradiation. Cell surface expression of CD45.1 (FITC-anti-CD45.1, clone A20) and CD45.2 (V450-anti-CD45.2, clone 104) on CD19+ (PercP-Cy5.5anti-CD19, clone 1D3) and CD4 ${ }^{+}$(PE-anti-CD19, clone RM4-5; BD Biosciences) gated cells was assessed by flow cytometry using a CyAn ADP Analyzer (Beckman Coulter). Data were analyzed with FlowJo software (Tree Star).

Cell proliferation assay. Caco-2 human adenocarcinoma cell line was maintained at $37^{\circ} \mathrm{C}$ and $5 \% \mathrm{CO}_{2}$ in Dulbecco's modified Eagle medium (Life Technologies) supplemented with $10 \%$ fetal calf serum and $1 \%$ penicillin-streptomycin (Sigma-Aldrich). Cells were seeded at $5 \times 10^{5}$ cells $/ \mathrm{ml}$ and cultured for 3 days. Cells were then pretreated

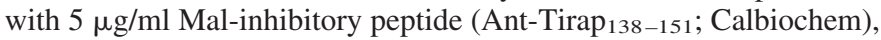
inhibitor peptide control (Ant-Tirap ${ }_{151-138}$; Calbiochem) or dimethyl sulfoxide (DMSO) for $2 \mathrm{~h}$. Following incubation, cell proliferation was assessed by the mitochondrial conversion of MTT to formazan by using a commercial kit (Sigma-Aldrich) according to manufacturer's instructions.

Statistics. Statistical analysis was performed by use of GraphPad Prism (La Jolla). Results are presented as means \pm SE $(n=6-8)$. The Mann-Whitney nonparametric test was used for the analysis of DAI and histology score. The $\chi^{2}$ test was used to evaluate the significance between the number of mice with or without neoformations. Differences, indicated as two-tailed $P$ values, were considered significant when $P<0.05$ as assessed by unpaired Student's $t$-test with Welch correction applied as necessary.

\section{RESULTS}

$\mathrm{Mal}^{-1-}$ mice are more susceptible to DSS-induced colitis. WT mice exposed to DSS in drinking water for 5 days followed by normal water for 5 days developed progressive weight loss (Fig. 1A) and signs of colitis detected by DAI scoring (Fig. $1 B$ ). Mal ${ }^{-1-}$ mice showed significantly $(P<$ 0.01-0.001) greater weight loss from day 6 and, unlike WT mice that regained weight from day 9, progressively lost weight (Fig. 1A). Furthermore, $\mathrm{Mal}^{-/-}$mice had a significantly $(P<0.05$ to $P<0.001)$ greater increase in DAI scores compared with WT mice (Fig. 1B). Although the severity of colitis in WT mice was reduced from days $8-10, \mathrm{Mal}^{-/-}$mice continued to lose weight with blood in the feces. At day 10, mice were euthanized and colon length was measured as a macroscopic index of tissue inflammation. $\mathrm{Mal}^{-/-}$mice had a significantly $(P<0.01)$ greater reduction in colon length compared with WT mice following DSS treatment (Fig. 1C). Additionally, the colons of untreated $\mathrm{Mal}^{-1-}$ mice were significantly $(P<0.05)$ shortened compared with age- and sex-matched WT (Fig. 1C). Histological analyses revealed that DSS treatment caused significantly $(P<0.05)$ more severe 
A

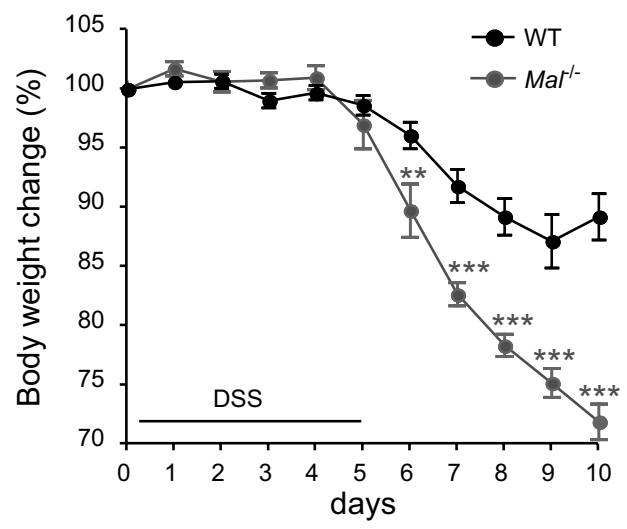

B

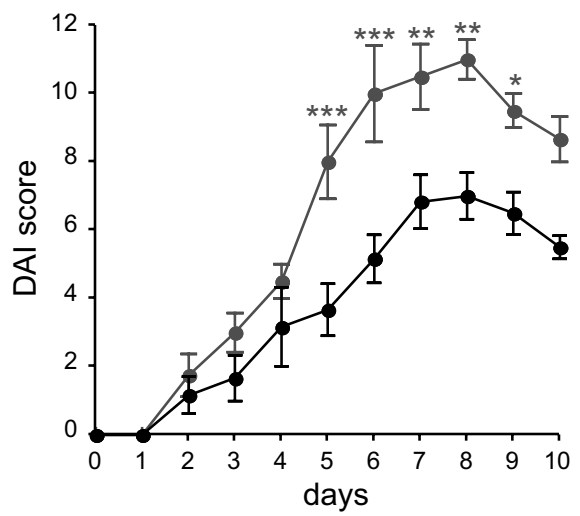

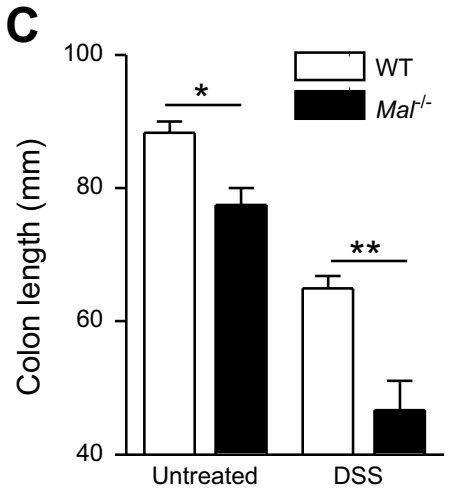

D

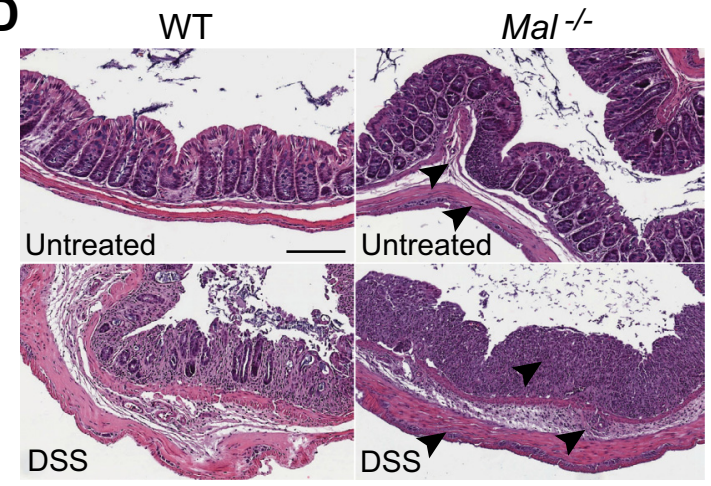

$\mathbf{F}$

E

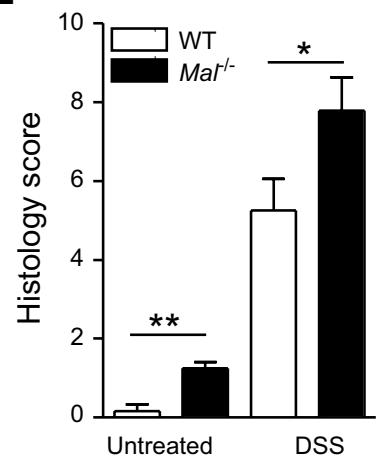

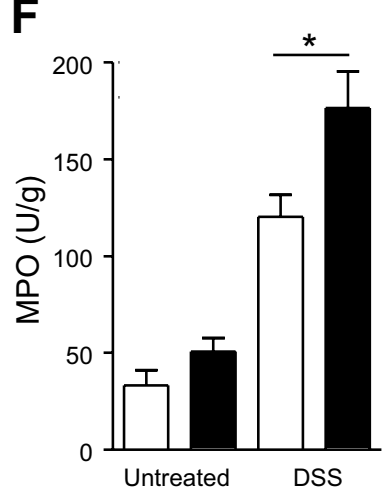

G

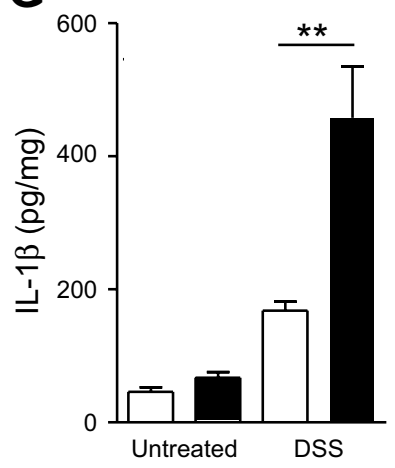

Fig. 1. MyD88 adaptor-like (Mal)-deficient $\left(\mathrm{Mal}^{-/-}\right)$mice are more susceptible to dextran sulfate sodium (DSS)-induced colitis. Body weight change $(A)$, disease activity index (DAI; $B)$, colon length $(C)$, histology ( $D$ and $E$; scale bars: $100 \mu \mathrm{m}$ ), colon myeloperoxidase (MPO; $F$ ), and Interleukin (IL)-1 $\beta(G)$ in sex- and age-matched wild-type (WT) and $\mathrm{Mal}^{-1-}$ mice. Data are expressed as means \pm SE $(n=6-8), * P<0.05, * * P<0.01$, and $* * * P<0.001$ vs. WT. pathology in the colons of $\mathrm{Mal}^{-/-}$mice compared with WT mice, with increases in submucosal edema, cell infiltration, and crypt damage (black arrows) (Fig. 1, D and E). Interestingly, correlating with the altered colon length of untreated $\mathrm{Mal}^{-{ }^{-1}}$ mice (Fig. 1C), the colons of these mice showed significant $(P<0.01)$ low-grade pathology compared with WT mice, with the presence of inflammatory cell infiltration and submucosal hyperplasia (black arrows) (Fig. 1, $D$ and $E$ ). To further substantiate the effect of Mal genetic ablation in DSS-induced colitis, we measured MPO and IL-1 $\beta$ as canonical markers of colon inflammation (6). DSS-treated $\mathrm{Mal}^{-/-}$mice had significantly $(P<0.05)$ increased MPO activity (Fig. $1 F)$ and $(P<$ $0.01)$ IL-1 $\beta$ levels (Fig. $1 G$ ) in the colons compared with DSS-treated WT mice. Interestingly, despite signs of inflammation in the colons of Mal-deficient mice in the steady state, there was no significant increase in colon levels of inflamma- tory markers between untreated WT and $\mathrm{Mal}^{-/-}$mice (Fig. 1, $F$ and $G)$. These data indicate that in the absence of Mal mice had increased susceptibility to develop colon inflammation in response to DSS-induced epithelial injury and further suggest the spontaneous development of subclinical colon inflammation in Mal-deficient mice.

Mal-deficient mice spontaneously develop colon inflammation and neoplastic lesions. As we had noted that Mal-deficient mice, 6-8 wk of age, had colon inflammation (Fig. 1, $C-E$ ), we further examined the colons of older $\mathrm{Mal}^{-1-}$ mice. In 6-mo-old Mal-deficient mice there were marked signs of colon inflammation, such as thicker muscularis propria, cell-infiltrated lamina propria, and more frequent foci of cell infiltration among crypts (black arrows) (Fig. 2, $A$ and $B$ ). Interestingly, in older mice (Fig. 2B) the extent of colon inflammation was not more severe relative to younger animals (Fig. 1D), indicating 
A
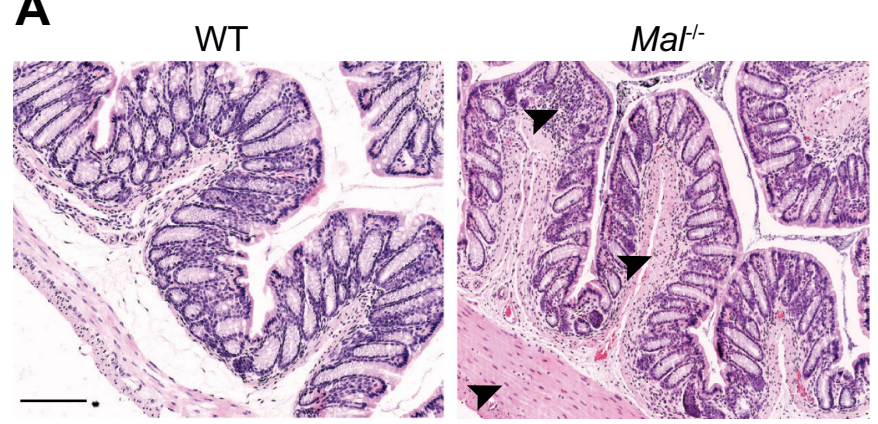

B

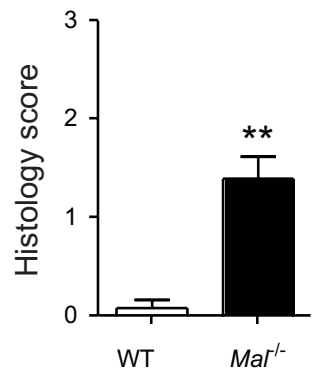

C

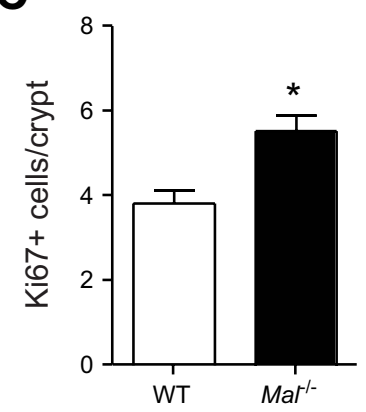
ages $(F)$ of colons stained with methylene blue in sex- and age-matched WT and $\mathrm{Mal}^{-1-}$ mice, and colon levels of IL-1 $\beta$, IL-6, IL-17A, and IL-17F (expressed in $\mathrm{pg} / \mathrm{mg}$ of tissue; $G$ ). Scale bars: $100 \mu \mathrm{m}$. Data are expressed as means \pm SE $(n=6), * P<0.05$ and $* * P<0.01$ vs. WT; ns, not significant.
Fig. 2. Adult Mal-deficient mice spontaneously develop intestinal inflammation and dysplasia. Representative images (hematoxylin and eosin staining; $A$ ) and histology score (B), crypt cell proliferation $\left(\mathrm{Ki}^{+} 7^{+}, C\right)$, and death (TUNEL ${ }^{+}$. $D)$, tumor number $(E)$, and representative im-
$F$

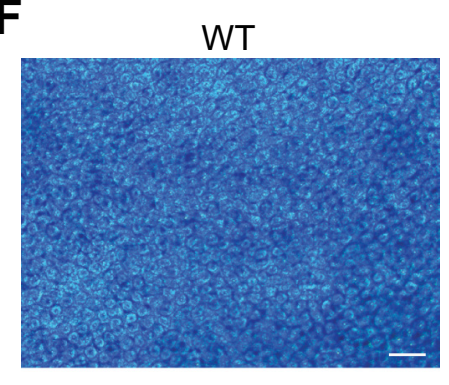

$\mathrm{Mal}^{-1-}$

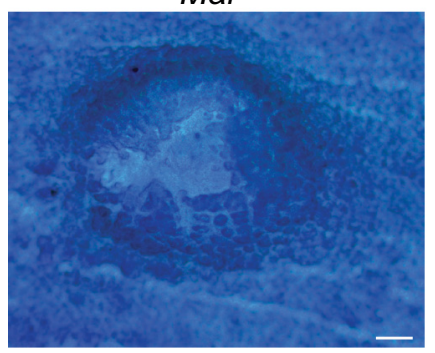

D

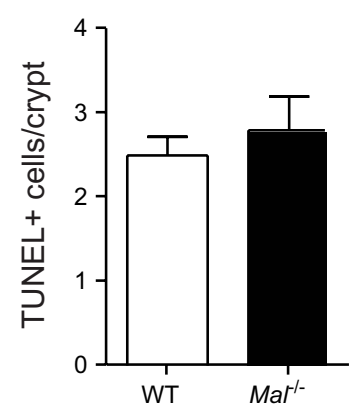

G
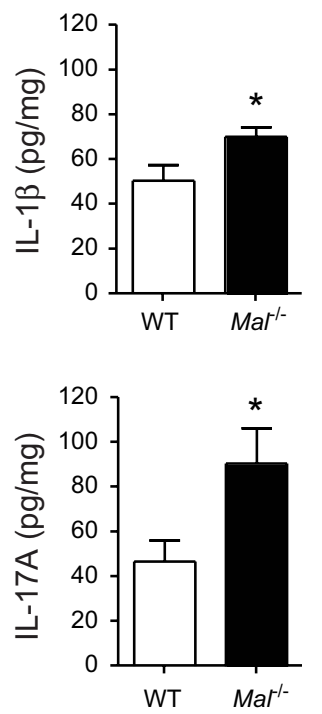

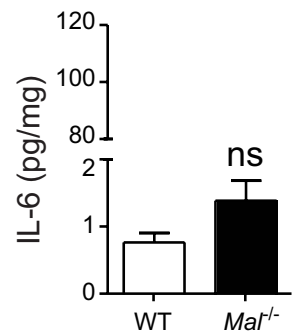

E
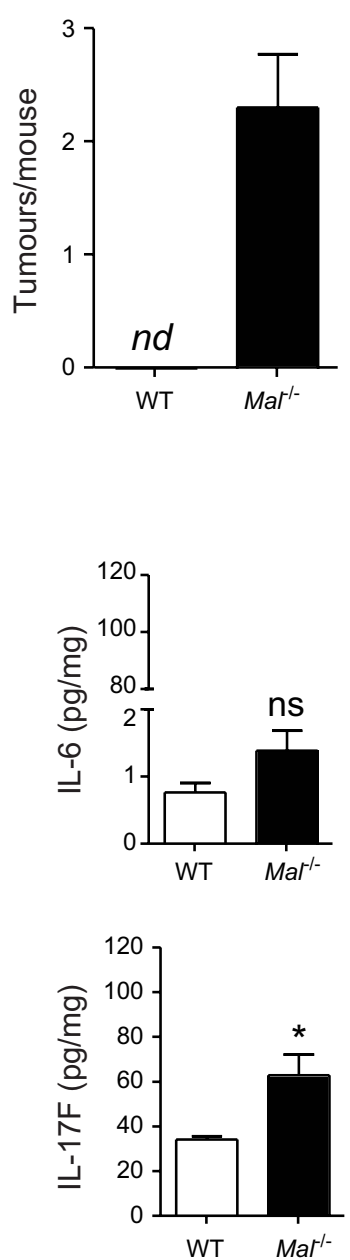

that the degree of colon inflammation did not progressively increase up to 6 mo of age.

To further address the spontaneous development of colon inflammation in $\mathrm{Mal}^{-/-}$mice we evaluated epithelial cell turnover by studying the rate of cell proliferation and death (enumeration of $\mathrm{Ki}^{+} 7^{+}$and $\mathrm{TUNEL}^{+}$cells, respectively) in colon epithelial cells. Adult $\mathrm{Mal}^{-1-}$ mice had a significant $(P<0.05)$ increase in Ki67-expressing cells in colon crypts compared with WT mice (Fig. 2C). To further examine whether inhibition of Mal altered cell proliferation, Caco-2 human adenocarcinoma cells were incubated in vitro with a Mal inhibitor peptide and control peptide. There was no dif- ference in proliferation of Caco-2 cells when treated with Mal inhibitor peptide [\% of cell proliferation relative to untreated (DMSO) cells: Mal inhibitor peptide: $99.70 \pm 17.5$, peptide control: $84.14 \pm 19.7$, means \pm SE, $n=6]$.

There was no difference in the $\mathrm{TUNEL}^{+}$cells between the two groups (Fig. 2D), suggesting that Mal deficiency did not directly affect the cell death process in the crypt turnover. The MB staining was then used for the macroscopic evaluation of potential colon neoformations as previously described (7). Focal lesions of the colonic mucosa were easily detectable prior to MB staining of fixed whole-mount preparations of colon since they presented enlarged dysmorphic crypts, com- 
pression of surrounding epithelium, darkly colored staining, and raised circular masses (Fig. 2, $E$ and $F$ ). Whereas WT mice showed no focal lesions, sex- and age-matched adult (6-moold) $\mathrm{Mal}^{-1-}$ mice developed an average of two neoformations per mouse colon (Fig. 2, $E$ and $F$ ). The frequency of Maldeficient mice bearing alterations in the colon epithelium was $71.4 \%\left(\chi^{2} 3.462, P=0.0314\right)$. Analysis of proinflammatory cytokines in colons of WT and $\mathrm{Mal}^{-1-}$ demonstrated that Mal-deficient mice had significantly $(P<0.05)$ increased levels of IL-1 $\beta$, IL-17A, and IL-17F, but not IL-6, compared with WT mice (Fig. 2G). These data indicate that under normal conditions adult Mal-deficient mice spontaneously develop low-grade colon inflammation and neoplasia.

Mal deficiency increases the development of tumors in a model of CAC. Because chronic inflammation is strongly correlated to the risk of developing colon cancer (34), we hypothesized that the chronic low levels of inflammation in mice deficient in Mal may predispose to the development of colon neoplasia. To address this point, WT and $\mathrm{Mal}^{-1-}$ mice were studied in the well-established model of CAC based on the coadministration of DSS and the organotropic colon carcinogen AOM (33). Mice were injected intraperitoneally with AOM on day 1 (week 0 ) and then underwent three 5-day cycles of DSS in drinking water (weeks 1, 4, and 7) (see protocol in Fig. 3A). Similar to the acute DSS model (Fig. 1), in the chronic model of CAC, 6- to 8-wk-old $\mathrm{Mal}^{-{ }^{-}}$mice developed significantly more colon inflammation than WT mice, including elevated DAI (Fig. $3 B ; P<0.05$ ), greater colon length shortening (Fig. $3 C ; P<0.05$ ), and higher histology scores (Fig. $3 D ; P<0.001$ ). More interestingly, the macroscopic analyses of colons demonstrated that $\mathrm{Mal}^{-/-}$mice had a significant $(P<0.001)$ increase in both tumor number (Fig. $3 E ; P<0.001$ ) and size (Fig. $3 F ; P<0.01)$ compared with WT. In particular, epithelia of $\mathrm{Mal}^{-/-}$mice were characterized by the presence of enlarged dysplastic masses, increased mucosal tissue aberration with more foci of regenerative crypts, and increased submucosal cell infiltrations (Fig. 3, $G$ and $H$ ). These data suggested a crucial role for Mal in regulating the
A

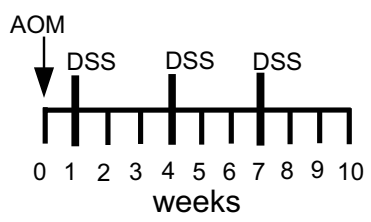

D

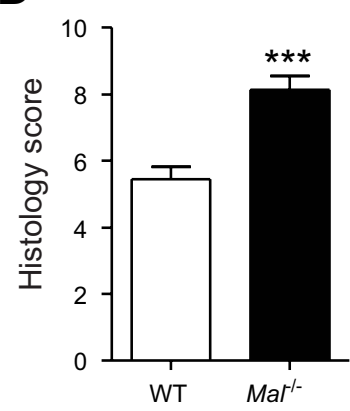

G

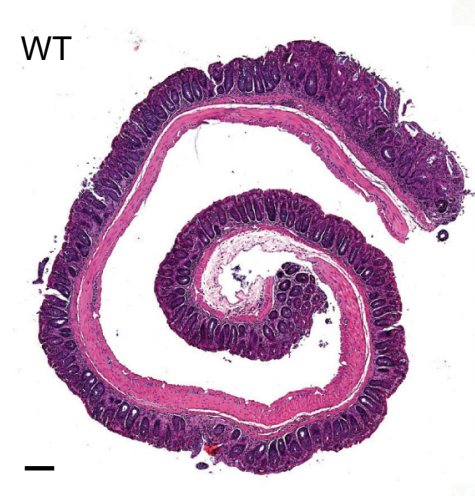

B

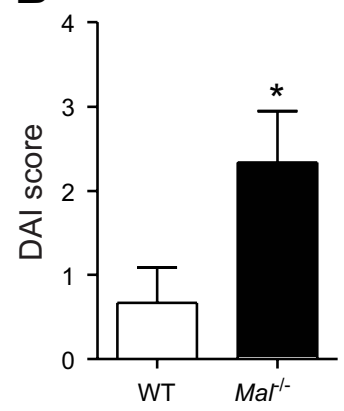

E

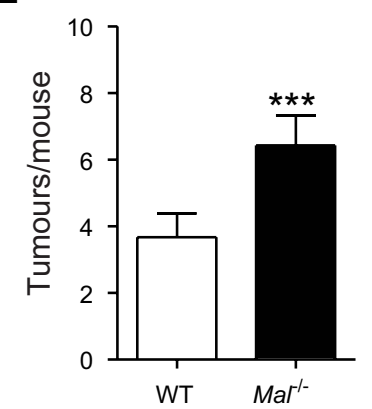

C

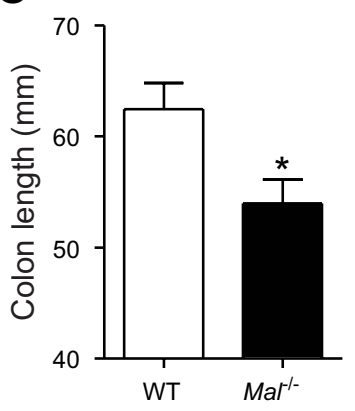

$\mathbf{F}$

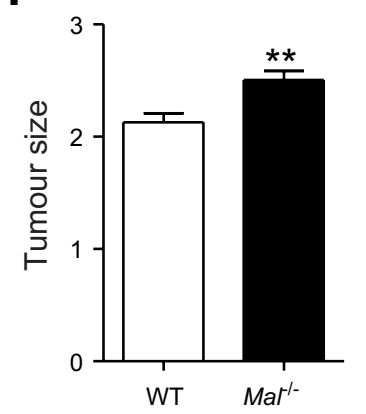

$\mathrm{H}$

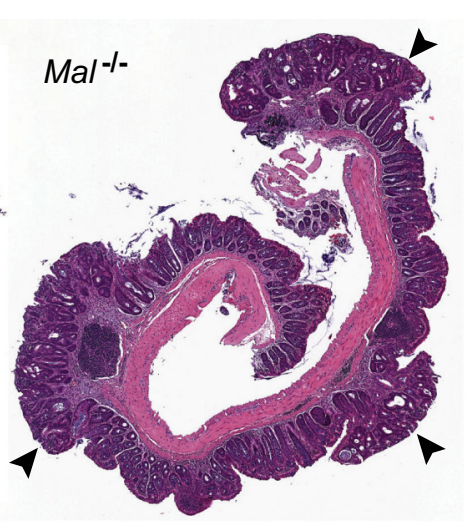

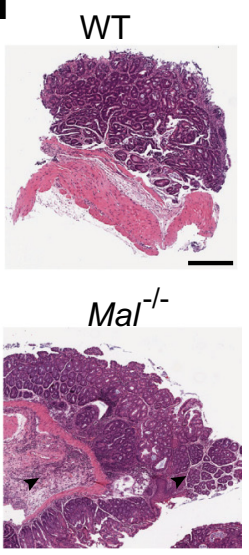

Fig. 3. Mal deficiency promotes the development of colitis-associated cancer. Protocol used for the development of colitis-associated cancer (CAC) based on the coadministration of azoxymethane (AOM, $10 \mathrm{mg} / \mathrm{kg}$, ip at day $1)$ and DSS $(2.5 \% \mathrm{wt} / \mathrm{vol}$ in 3 cycles of 5 days each at week 1, 4, and 7) (A), DAI score $(B)$, colon length $(C)$, histology score $(D)$, tumor number $(E)$, and tumor size $(F)$ in sex- and age-matched WT and $\mathrm{Mal}^{-1-}$ mice. Representative images of whole colons $(G)$ and tumors $(H)$ of WT and $\mathrm{Mal}^{-1-}$ mouse colons at the termination of the study (scale bars: 100 $\mu \mathrm{m})$. Data are expressed as means $\pm \mathrm{SE}(n=$ 8), ${ }^{*} P<0.05,{ }^{*} P P<0.01$, and $* * * P<0.001$ vs. WT. 
inflammatory response in the colon and progression to associated colorectal tumor formation and growth.

Mal expression in nonhematopoietic cells is involved in preventing the development of colon inflammation and tumorigenesis. We have shown that Mal deficiency rendered mice prone to the development of spontaneous and inducible colon inflammation and cancer (Fig. 1-3). Given the presence of Mal in both myeloid $(23,50)$ and nonmyeloid (12) cells, we next aimed to understand whether the development of colon inflammation and cancer in $\mathrm{Mal}^{-/-}$mice was due to its absence in the hematopoietic or nonhematopoietic cell compartment. To address this we generated bone marrow chimeric mice (see protocol in Fig. 4) of the following groups (donor $>$ recipient): WT $>$ WT, WT $>\mathrm{Mal}^{-\prime-}, \mathrm{Mal}^{-/-}>\mathrm{WT}$, and $\mathrm{Mal}^{-\prime-}>$ $\mathrm{Mal}^{-\prime-}$. Mice were subjected to DSS-induced epithelial damage and AOM/DSS elicited CAC.

Mal-deficient chimeric mice $\left(\mathrm{Mal}^{-/-}>\mathrm{Mal}^{-/-}\right)$had more severe colitis than wild-type (WT $>$ WT) chimeras, as indicated by reduced colon length (Fig. $5 A ; P<0.05$ ), increased colon inflammation (Fig. 5, $B$ and $C ; P<0.01$ ) and elevated SAA levels (Fig. $5 D ; P<0.01$ ). With respect to Mal deficiency in hematopoietic or nonhematopoietic cells, following DSS treatment, mice with nonhematopoietic Mal deficiency (WT $>\mathrm{Mal}^{-1-}$ ) had more severe disease relative to mice with deficiency in hematopoietic cells $\left(\mathrm{Mal}^{-1-}>\mathrm{WT}\right)$, as observed by colon length (Fig. 5A; $P<0.05$ and $P<0.01$ ), pathology score (Fig. 5, $B$ and $C ; P<0.01$ ), and SAA levels (Fig. $5 D ; P<$ $0.01)$. Therefore, these data demonstrated that deficiency of Mal in nonhematopoietic cells leads to more severe DSSinduced epithelial damage and resulting colon inflammation.

We further investigated the development of CAC in bone marrow chimeric mice, using the regime adopted above (Fig. $3 A$ ). During the $10 \mathrm{wk}$ chimeras with deficiency of Mal in nonhematopoietic cells (groups WT $>\mathrm{Mal}^{-/-}$and $\mathrm{Mal}^{-/-}>$ $\mathrm{Mal}^{-1-}$ ) had more marked weight loss relative to groups of chimeras with functional Mal in nonhematopoietic cells (groups WT $>$ WT and $\mathrm{Mal}^{-/-}>$WT) (Fig. $6 A ; P<0.05$ vs. WT $>$ WT group). Furthermore, irradiated $\mathrm{Mal}^{-/-}$mice reconstituted with $\mathrm{Mal}^{-/-}$bone marrow $\left(\mathrm{Mal}^{-/-}>\mathrm{Mal}^{-{ }^{-}}\right)$had greater disease compared with WT $>$ WT chimeras, with significant differences in colon length (Fig. $6 B ; P<0.001$ ), tumor number (Fig. $6 C ; P<0.01$ ), and SAA levels (Fig. $6 D$; $P<0.01)$. These data from bone marrow chimeras recapitulate the more severe phenotype observed in Mal-deficient mice relative to WT mice (Figs. 1-3). More importantly, chimeras with selective nonhematopoietic cell deficiency in Mal (WT $>$ $\mathrm{Mal}^{-1-}$ ) had significantly reduced colon length (Fig. $6 B ; P<$ 0.001 ), increased tumor frequency (Fig. $6 C ; P<0.05$ ), and increased SAA levels (Fig. $6 D ; P<0.001$ ) relative to WT $(\mathrm{WT}>\mathrm{WT}$ ) chimeras. Collectively these data demonstrated that Mal expression in nonhematopoietic cells plays a crucial protective role in the development of both colon inflammation and tumorigenesis.

\section{DISCUSSION}

In this study, using mouse models of colon inflammation and cancer, a role for the signaling protein Mal in the regulation of intestinal homeostasis and the development of inflammation/ cancer was described. It was further shown by using bone marrow chimeras that the expression of Mal in nonhematopoietic cells has a protective role in preventing intestinal inflammation and tumorigenesis.

An intact gut epithelial barrier is a prerequisite for normal health. Along the whole gastrointestinal tract a single layer of cells must 1 ) provide physical protection from the potentially irritant and antigenic substances present in the luminal compartment and 2) perform essential biological functions such as absorption, secretion, and transport of nutrients and water. The activation of TLRs regulates cell survival and tissue regener-
Fig. 4. Generation of bone marrow (BM) chimeric mice. $A$; protocol for the generation of bone marrow chimeras. CD $45.1^{+} \mathrm{WT}$ and $\mathrm{CD} 45.2^{+} \mathrm{Mal}^{-1-}$ recipient mice were lethally irradiated with 9 Gy ( 2 divided doses 3 $\mathrm{h}$ apart) and injected intravenously (i.v.) with $1 \times 10^{7}$ cells per mouse from CD $45.1^{+}$WT or CD45.2 $2^{+} \mathrm{Mal}^{-1-}$ mice. The following 4 chimera groups were generated: WT $>$ WT, $\mathrm{WT}>\mathrm{Mal}^{-/-}, \mathrm{Mal}^{-{ }^{-}-}>\mathrm{WT}$, and $\mathrm{Mal}^{-/-}>$ $\mathrm{Mal}^{-1-}$ (referred as "donor into recipient mice"). $B$ : representative flow cytometry plots showing the level of cell engraftment after 8-10 wk from the irradiation. Cells from blood were gated on $\mathrm{CD} 19^{+}$-expressing B cells.
A
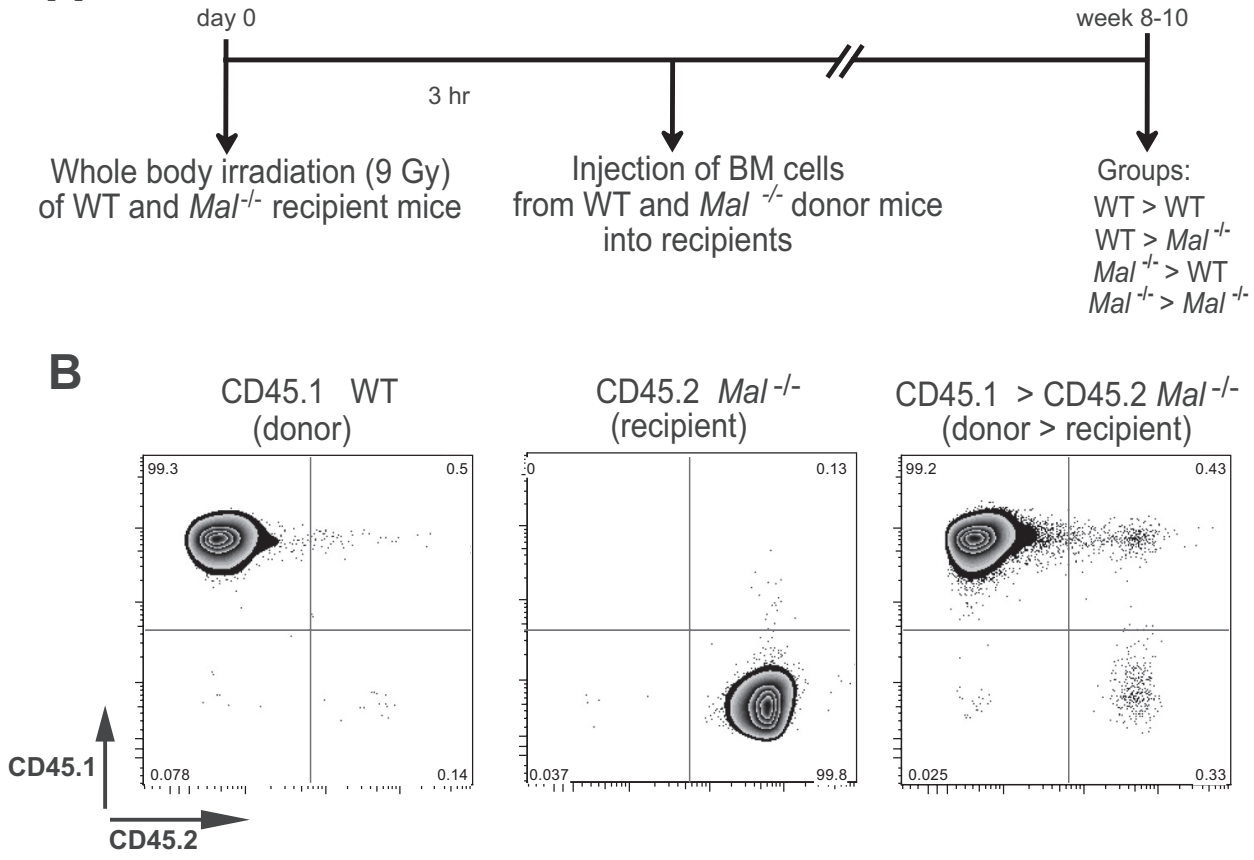
A

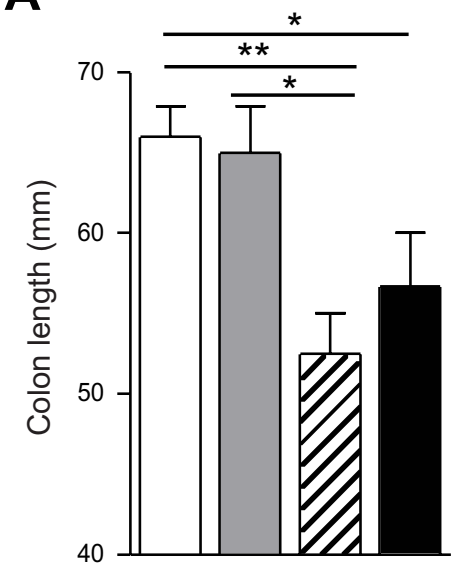

C

WT $>\mathrm{Mar}^{-/-}$

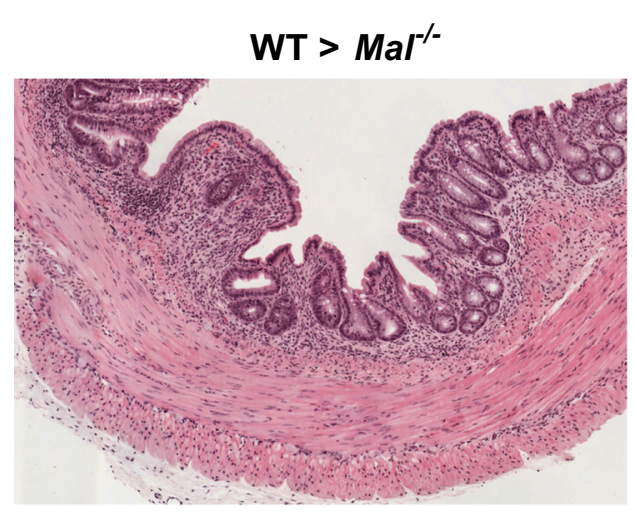

B

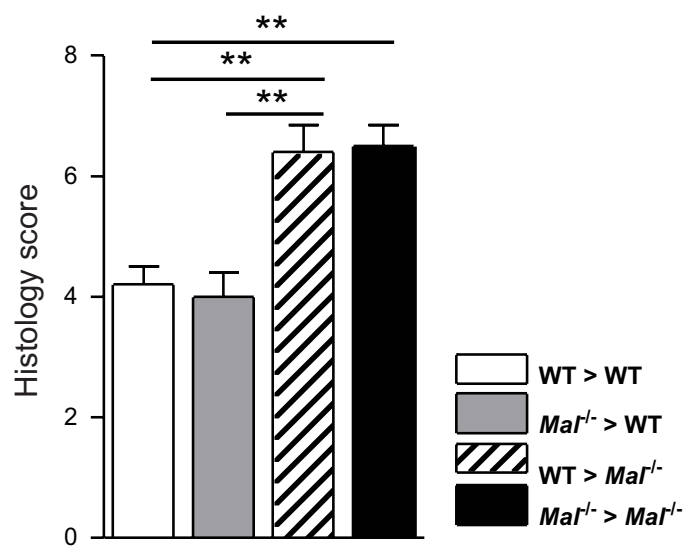

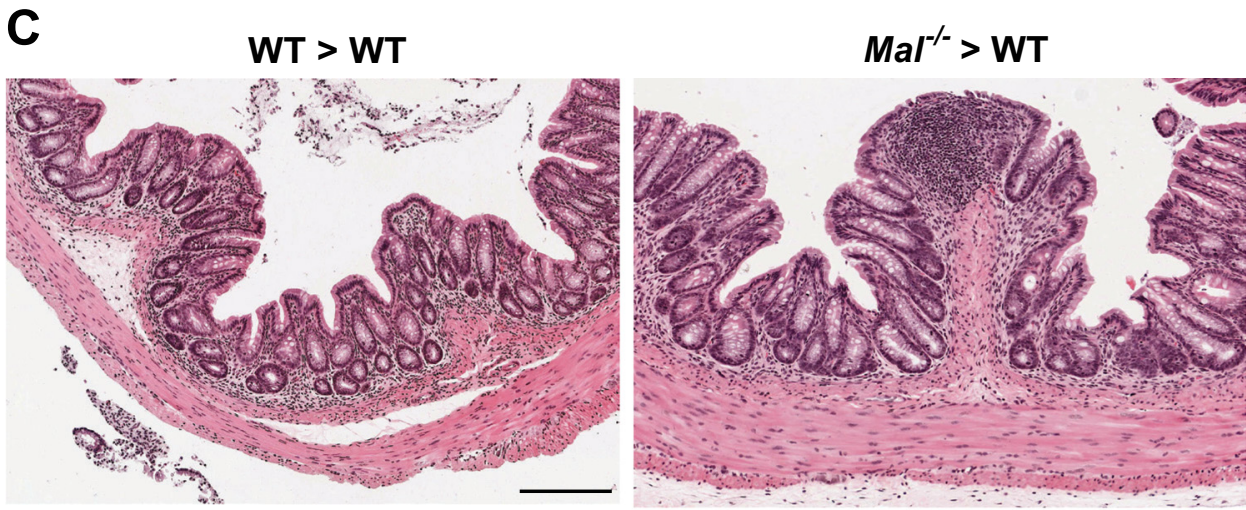

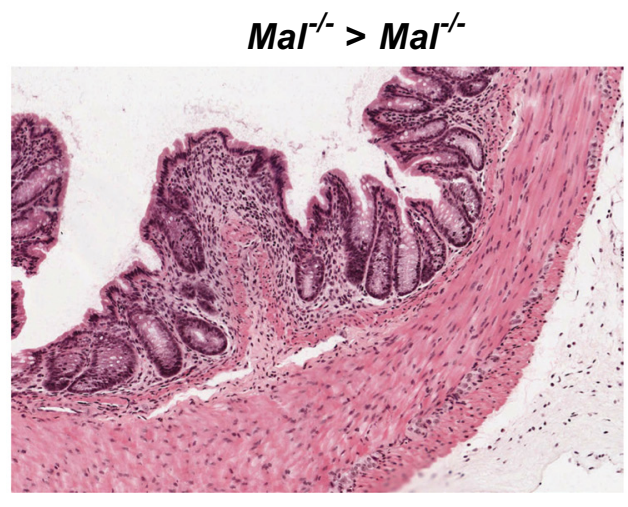

Fig. 5. Nonhematopoietic cell Mal deficiency renders mice susceptible to colitis. Colon length $(A)$, histology score $(B)$, and representative images $(C)$, and serum amyloid $\mathrm{A}$ (SAA) levels $(D)$ in the 4 groups of chimeric mice generated: WT $>\mathrm{WT}$, WT $>\mathrm{Mal}^{-1-}$, $\mathrm{Mal}^{-1-}>\mathrm{WT}$, and $\mathrm{Mal}^{-1-}>\mathrm{Mal}^{-1-}$ (donor $>$ recipient) (see protocol in Fig. 4). Scale bars: $100 \mu \mathrm{m}$. Data are expressed as means $\pm \operatorname{SE}(n=6), * P<0.05$ and $* * P<$ 0.01 vs. relative control (see text).

D

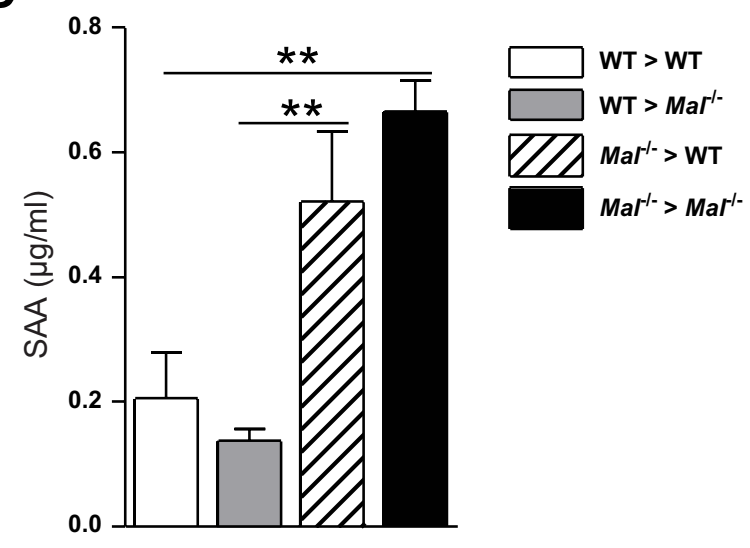


Fig. 6. Nonhematopoietic cell Mal deficiency is involved in colon cancer development. Body weight change $(A)$, colon length $(B)$, tumor number $(C)$, and SAA levels $(D)$ in the 4 groups of chimeric mice generated: WT $>$ WT, WT $>$ $\mathrm{Mal}^{-1-}, \mathrm{Mal}^{-1-}>\mathrm{WT}$, and $\mathrm{Mal}^{-1-}>\mathrm{Mal}^{-1-}$ (donor $>$ recipient) (see protocol in Fig. 4). Data are expressed as means $\pm \operatorname{SE}(n=5-6), * P<$ $0.05, * * P<0.01$, and $* * * P<0.001$ vs. relative control (see text).

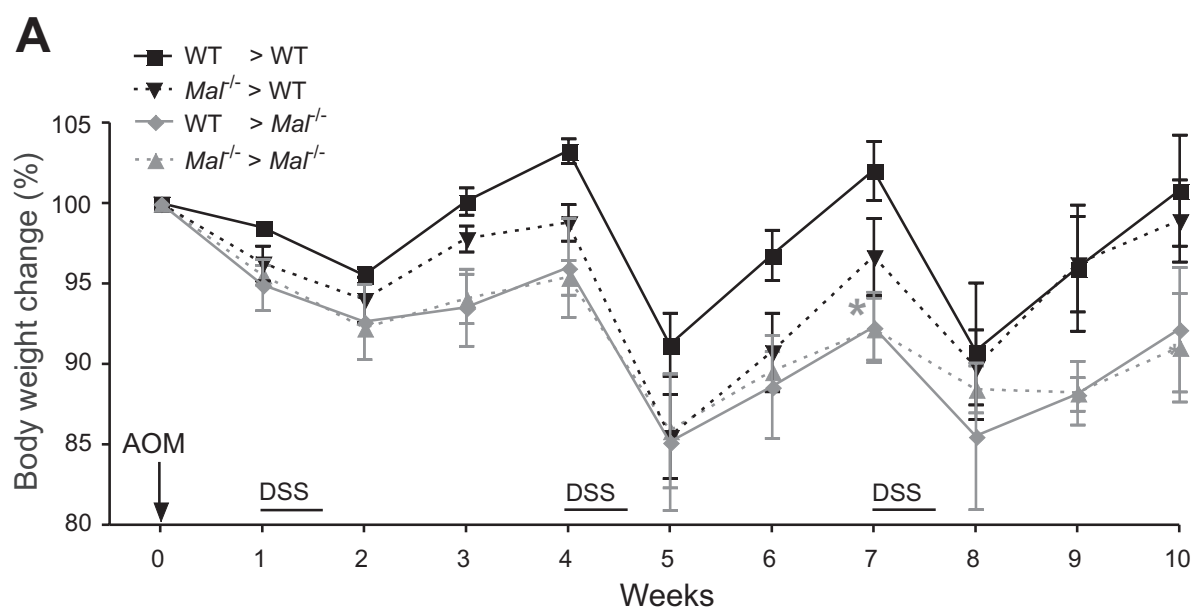

B

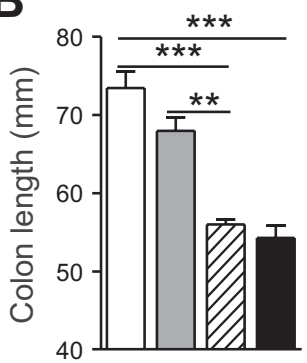

C

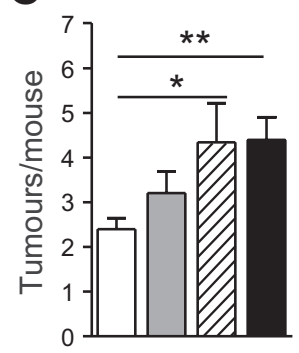

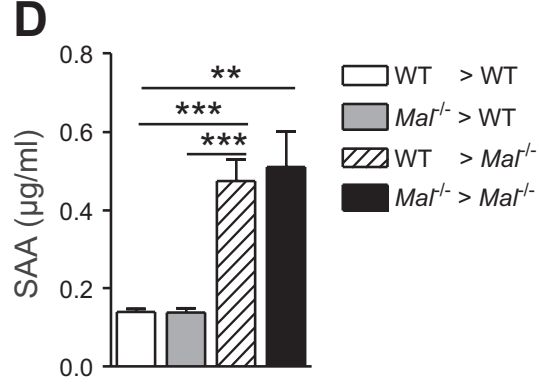

ation in the gut by promoting the nuclear translocation of $\mathrm{NF}-\kappa \mathrm{B}$ and thus the transcription of crucial factors involved in epithelial homeostasis (48). During the steady state within the intestine, activation of TLRs culminates in cellular responses, such as antimicrobial peptide production, inflammation, maturation of antigen-presenting cells, and induction of tissue repair and cell survival pathways, aimed at killing microorganisms and preserving host cell integrity (40). Dysfunctional TLR signaling to intestinal microflora is a central component of the pathogenesis of IBD (11), with commensal bacteria being directly responsible for altered mucosal immune balance $(4$, 37), leading to persistent inflammatory response (10). Indeed, changes in composition (dysbiosis) of the gut commensal microbiota in patients and mice have been linked to tumorpromoting effects (42).

Mal has been described as a bridging adapter, responsible for the specific recruitment of MyD88 to the cytosolic surface of TLR2 and TLR4 receptors $(18,46)$. The function of MyD88 in orchestrating intestinal pathophysiology, including shaping the composition of resident gut microbiota (20), is documented $(2,25,39)$. However, the role of Mal in the pathogenesis of intestinal inflammation and cancer is not defined, or indeed effects on the gut microbiome. Corr et al. (13) have recently shown that Mal-deficient mice have perturbed intestinal epithelial barrier integrity and that in the absence of Mal there is an increased susceptibility to bacterial infection via the oral route.

In this study, the intestinal pathology induced by the DSS model of epithelial damage and colitis was more severe in $\mathrm{Mal}^{-/-}$mice, as observed by multiple parameters including reduced colon length, increased body weight loss, DAI (cumulative of stool consistency and bleeding), histology, and colon levels of IL-1 $\beta$ and MPO. Interestingly, in the steady state $\mathrm{Mal}^{-/-}$mice displayed subclinical intestinal inflammation, with colon shortening and inflammation with increases in levels of IL-1 $\beta$, IL-17A, and IL1-7F in the colons compared with age- and sex-matched WT mice housed in the same facility. Furthermore, adult $\mathrm{Mal}^{-/-}$mice spontaneously developed epithelial hyperproliferation and dysplasia, likely as a result of progression from chronic low levels of colon inflammation.

In light of the role that Mal has in TLR-mediated inflammatory phenomena (46), and considering that $\mathrm{Mal}^{-/-}$mice showed increased mucosal and submucosal cell infiltration, we hypothesized that chronic inflammation in Mal-deficient mice could represent a predisposing factor to the development of tumors. Indeed, although inflammation is an indispensable adaptive response (29), a prolonged inflammatory state can promote the development of cancer in the gut (43) through mechanisms involving intestinal microbiota (3) or identify host genetic factors capable of controlling bacteria-driven colitis and cancer (9). The risk to IBD patients of developing cancer is proportional to the duration and extent of inflammation, hence the development of CAC (43). In particular, colonic dysplasia in IBD and colon cancer is thought to be the result of repeated cycles of epithelial cell injury and repair (44). In this study we used the combined AOM/DSS murine model that reproduces core features of human CAC (33). Micro- and macroscopic analysis of colons revealed that $\mathrm{Mal}^{-/-}$mice formed more tumors upon administration of AOM/DSS, thus suggesting that Mal signaling contributes to tumor growth in the colon. Thus collectively data from DSS and CAC experiments indicate a role for Mal in intestinal tissue repair mechanisms (occurring during inflammation) and the development 
of colon cancer at the level of TLR-mediated molecular recognition. Polymorphisms in $M A L$ have been previously associated with both colitis and CAC. A genetic analysis study of North American IBD cases found a modest association between $M A L$ and IBD whereas a meta-analysis of six Crohn's disease genomewide association studies in Europe found no significant association with $M A L(16,19)$. More recently, it has been reported that single nucleotide polymorphisms in $M A L$ may alter the course of survival in patients with colorectal cancer (26). It remains to be determined by what mechanism Mal orchestrates the homeostatic response to colon injury and whether other mechanisms ancillary to tumor promotion are also involved.

An abnormal inflammatory response is tightly coupled with carcinogenesis (43). Tumor promotion and progression are associated with the production of numerous inflammatory mediators, including cytokines and chemokines, the recruitment and activation of immune cells (21). Substantial advances in cancer research have delineated protumorigenic roles for immune cell subsets that are, in some circumstances, crucial players in CAC (15). Activation of TLRs and subsequent NF- $\mathrm{KB}$ and MAPK signaling pathways occurs in myeloid cells and also nonmyeloid cells such as epithelial cells that facilitate recognition of microbial components at the intestinal level (1). Proinflammatory mediators secreted not only by hematopoietic cells that infiltrate inflamed tissue (extrinsic inflammation) but also by epithelial, stromal, and endothelial cells (intrinsic inflammation) may affect the cell proliferation and function (38). Here, we generated chimeric mice with loss of Mal in these two distinct cell compartments (22), to address the relative role of expression of Mal in hematopoietic or nonhematopoietic cells in the development of colitis and colitisassociated cancer. Genetic ablation of Mal in nonhematopoietic cells led to greater susceptibility of mice to intestinal inflammation and tumorigenesis. In the first instance, these data indicate that the expression of Mal in the colon epithelium may function in maintenance of intestinal homeostasis in the context of inflammation and also carcinogenesis. Nevertheless, our in vitro studies on epithelial adenocarcinoma cells showed that the inhibition of Mal did not affect cell proliferation. These data may be due to a primary role of other-than-epithelial cells, such as stromal or endothelial cells. Thus further studies are needed to uncover the biology of Mal in the colon mucosa. In conclusion, this study shows that Mal signaling in nonhematopoietic cells has a crucial role in the maintenance of normal intestinal homeostasis and the development of colon inflammation and associated tumorigenesis.

\section{GRANTS}

This work was supported by grants from Science Foundation Ireland.

\section{DISCLOSURES}

No conflicts of interest, financial or otherwise, are declared by the author(s).

\section{AUTHOR CONTRIBUTIONS}

G.A. and D.G.J. performed experiments; G.A. and S.C.C. analyzed data; G.A. and P.G.F. interpreted results of experiments; G.A. prepared figures; G.A. and P.G.F. drafted manuscript; S.C.C., L.A.O., and P.G.F. edited and revised manuscript; P.G.F. conception and design of research; P.G.F. approved final version of manuscript.

\section{REFERENCES}

1. Abreu MT. Toll-like receptor signalling in the intestinal epithelium: how bacterial recognition shapes intestinal function. Nat Rev Immunol 10: 131-144, 2010.

2. Araki A, Kanai T, Ishikura T, Makita S, Uraushihara K, Iiyama R, Totsuka T, Takeda K, Akira S, Watanabe M. MyD88-deficient mice develop severe intestinal inflammation in dextran sodium sulfate colitis. $J$ Gastroenterol 40: 16-23, 2005.

3. Arthur JC, Perez-Chanona E, Muhlbauer M, Tomkovich S, Uronis JM, Fan TJ, Campbell BJ, Abujamel T, Dogan B, Rogers AB, Rhodes JM, Stintzi A, Simpson KW, Hansen JJ, Keku TO, Fodor AA, Jobin C. Intestinal inflammation targets cancer-inducing activity of the microbiota. Science 338: 120-123, 2012.

4. Artis D. Epithelial-cell recognition of commensal bacteria and maintenance of immune homeostasis in the gut. Nat Rev Immunol 8: 411-420, 2008.

5. Asquith MJ, Boulard O, Powrie F, Maloy KJ. Pathogenic and protective roles of MyD88 in leukocytes and epithelial cells in mouse models of inflammatory bowel disease. Gastroenterology 139: 519-529, 529.e1-e2, 2010.

6. Aviello G, Amu S, Saunders SP, Fallon PG. A mineral extract from red algae ameliorates chronic spontaneous colitis in IL-10 deficient mice in a mouse strain dependent manner. Phytother Res 28: 300-304, 2014.

7. Aviello G, Romano B, Borrelli F, Capasso R, Gallo L, Piscitelli F, Di Marzo V, Izzo AA. Chemopreventive effect of the non-psychotropic phytocannabinoid cannabidiol on experimental colon cancer. J Mol Med (Berl) 90: 925-934, 2012.

8. Beaugerie L, Svrcek M, Seksik P, Bouvier AM, Simon T, Allez M, Brixi H, Gornet JM, Altwegg R, Beau P, Duclos B, Bourreille A, Faivre J, Peyrin-Biroulet L, Flejou JF, Carrat F. Risk of colorectal high-grade dysplasia and cancer in a prospective observational cohort of patients with inflammatory bowel disease. Gastroenterology 145: 166175 e168, 2013.

9. Boulard O, Kirchberger S, Royston DJ, Maloy KJ, Powrie FM. Identification of a genetic locus controlling bacteria-driven colitis and associated cancer through effects on innate inflammation. J Exp Med 209: 1309-1324, 2012.

10. Bruno ME, Frantz AL, Rogier EW, Johansen FE, Kaetzel CS. Regulation of the polymeric immunoglobulin receptor by the classical and alternative NF-kappaB pathways in intestinal epithelial cells. Mucosal Immunol 4: 468-478, 2011.

11. Cario E. Toll-like receptors in inflammatory bowel diseases: a decade later. Inflamm Bowel Dis 16: 1583-1597, 2010.

12. Choi YJ, Jung J, Chung HK, Im E, Rhee SH. PTEN regulates TLR5induced intestinal inflammation by controlling Mal/TIRAP recruitment. FASEB J 27: 243-254, 2013.

13. Corr SC, Palsson-McDermott EM, Grishina I, Barry SP, Aviello G, Bernard NJ, Casey PG, Ward JB, Keely SJ, Dandekar S, Fallon PG, O'Neill LA. MyD88 adaptor-like (Mal) functions in the epithelial barrier and contributes to intestinal integrity via protein kinase C. Mucosal Immunol 7: 57-67, 2014.

14. Coste I, Le Corf K, Kfoury A, Hmitou I, Druillennec S, Hainaut P, Eychene A, Lebecque S, Renno T. Dual function of MyD88 in RAS signaling and inflammation, leading to mouse and human cell transformation. J Clin Invest 120: 3663-3667, 2010.

15. Coussens LM, Zitvogel L, Palucka AK. Neutralizing tumor-promoting chronic inflammation: a magic bullet? Science 339: 286-291, 2013.

16. De Jager PL, Franchimont D, Waliszewska A, Bitton A, Cohen A, Langelier D, Belaiche J, Vermeire S, Farwell L, Goris A, Libioulle C, Jani N, Dassopoulos T, Bromfield GP, Dubois B, Cho JH, Brant SR, Duerr RH, Yang H, Rotter JI, Silverberg MS, Steinhart AH, Daly MJ, Podolsky DK, Louis E, Hafler DA, Rioux JD. The role of the Toll receptor pathway in susceptibility to inflammatory bowel diseases. Genes Immun 8: 387-397, 2007.

17. Duran-Struuck R, Dysko RC. Principles of bone marrow transplantation (BMT): providing optimal veterinary and husbandry care to irradiated mice in BMT studies. J Am Assoc Lab Anim Sci 48: 11-22, 2009.

18. Fitzgerald KA, Palsson-McDermott EM, Bowie AG, Jefferies CA, Mansell AS, Brady G, Brint E, Dunne A, Gray P, Harte MT, McMurray D, Smith DE, Sims JE, Bird TA, O’Neill LA. Mal (MyD88adapter-like) is required for Toll-like receptor-4 signal transduction. $\mathrm{Na}$ ture 413: 78-83, 2001. 
19. Franke A, McGovern DP, Barrett JC, Wang K, Radford-Smith GL, Ahmad T, Lees CW, Balschun T, Lee J, Roberts R, Anderson CA, Bis JC, Bumpstead S, Ellinghaus D, Festen EM, Georges M, Green T, Haritunians T, Jostins L, Latiano A, Mathew CG, Montgomery GW, Prescott NJ, Raychaudhuri S, Rotter JI, Schumm P, Sharma Y, Simms LA, Taylor KD, Whiteman D, Wijmenga C, Baldassano RN, Barclay M, Bayless TM, Brand S, Buning C, Cohen A, Colombel JF, Cottone M, Stronati L, Denson T, De Vos M, D'Inca R, Dubinsky M, Edwards C, Florin T, Franchimont D, Gearry R, Glas J, Van Gossum A, Guthery SL, Halfvarson J, Verspaget HW, Hugot JP, Karban A, Laukens D, Lawrance I, Lemann M, Levine A, Libioulle C, Louis E, Mowat C, Newman W, Panes J, Phillips A, Proctor DD, Regueiro M, Russell R, Rutgeerts P, Sanderson J, Sans M, Seibold F, Steinhart AH, Stokkers PC, Torkvist L, Kullak-Ublick G, Wilson D, Walters T, Targan SR, Brant SR, Rioux JD, D'Amato M, Weersma RK, Kugathasan S, Griffiths AM, Mansfield JC, Vermeire S, Duerr RH, Silverberg MS, Satsangi J, Schreiber S, Cho JH, Annese V, Hakonarson H, Daly MJ, Parkes M. Genome-wide meta-analysis increases to 71 the number of confirmed Crohn's disease susceptibility loci. Nat Genet 42: $1118-1125,2010$.

20. Frantz AL, Rogier EW, Weber CR, Shen L, Cohen DA, Fenton LA, Bruno ME, Kaetzel CS. Targeted deletion of MyD88 in intestinal epithelial cells results in compromised antibacterial immunity associated with downregulation of polymeric immunoglobulin receptor, mucin-2, and antibacterial peptides. Mucosal Immunol 5: 501-512, 2012.

21. Grivennikov SI, Greten FR, Karin M. Immunity, inflammation, and cancer. Cell 140: 883-899, 2010.

22. Hermiston ML, Green RP, Gordon JI. Chimeric-transgenic mice represent a powerful tool for studying how the proliferation and differentiation programs of intestinal epithelial cell lineages are regulated. Proc Natl Acad Sci USA 90: 8866-8870, 1993.

23. Horng T, Barton GM, Flavell RA, Medzhitov R. The adaptor molecule TIRAP provides signalling specificity for Toll-like receptors. Nature 420: 329-333, 2002.

24. Horng T, Barton GM, Medzhitov R. TIRAP: an adapter molecule in the Toll signaling pathway. Nat Immunol 2: 835-841, 2001.

25. Kennedy CL, Najdovska M, Tye H, McLeod L, Yu L, Jarnicki A, Bhathal PS, Putoczki T, Ernst M, Jenkins BJ. Differential role of MyD88 and Mal/TIRAP in TLR2-mediated gastric tumourigenesis. Oncogene 2013 Jun 3. doi: 10.1038/onc.2013.205. [Epub ahead of print]

26. Klimosch SN, Forsti A, Eckert J, Knezevic J, Bevier M, von Schönfels W, Heits N, Walter J, Hinz S, Lascorz J, Hampe J, Hartl D, Frick JS, Hemminki K, Schafmayer C, Weber AN. Functional TLR5 genetic variants affect human colorectal cancer survival. Cancer Res 73: 72327242, 2013.

27. Lee CC, Avalos AM, Ploegh HL. Accessory molecules for Toll-like receptors and their function. Nat Rev Immunol 12: 168-179, 2012.

28. Maloy KJ, Powrie F. Intestinal homeostasis and its breakdown in inflammatory bowel disease. Nature 474: 298-306, 2011.

29. Medzhitov R. Origin and physiological roles of inflammation. Nature 454: 428-435, 2008.

30. Miggin SM, Palsson-McDermott E, Dunne A, Jefferies C, Pinteaux E, Banahan K, Murphy C, Moynagh P, Yamamoto M, Akira S, Rothwell N, Golenbock D, Fitzgerald KA, O'Neill LA. NF-kappaB activation by the Toll-IL-1 receptor domain protein MyD88 adapter-like is regulated by caspase-1. Proc Natl Acad Sci USA 104: 3372-3377, 2007.

31. Molodecky NA, Soon IS, Rabi DM, Ghali WA, Ferris M, Chernoff G, Benchimol EI, Panaccione R, Ghosh S, Barkema HW, Kaplan GG. Increasing incidence and prevalence of the inflammatory bowel diseases with time, based on systematic review. Gastroenterology 142: 46-54. e42; quiz e30, 2012.
32. Naugler WE, Sakurai T, Kim S, Maeda S, Kim K, Elsharkawy AM, Karin M. Gender disparity in liver cancer due to sex differences in MyD88-dependent IL-6 production. Science 317: 121-124, 2007.

33. Neufert C, Becker C, Neurath MF. An inducible mouse model of colon carcinogenesis for the analysis of sporadic and inflammation-driven tumor progression. Nat Protoc 2: 1998-2004, 2007.

34. Ording AG, Horvath-Puho E, Erichsen R, Long MD, Baron JA, Lash TL, Sorensen HT. Five-year mortality in colorectal cancer patients with ulcerative colitis or Crohn's disease: a nationwide population-based cohort study. Inflamm Bowel Dis 19: 800-805, 2013.

35. Podolsky DK. Inflammatory bowel disease. N Engl J Med 347: 417-429, 2002.

36. Rakoff-Nahoum S, Medzhitov R. Regulation of spontaneous intestinal tumorigenesis through the adaptor protein MyD88. Science 317: 124-127, 2007.

37. Rakoff-Nahoum S, Paglino J, Eslami-Varzaneh F, Edberg S, Medzhitov R. Recognition of commensal microflora by toll-like receptors is required for intestinal homeostasis. Cell 118: 229-241, 2004.

38. Salcedo R, Cataisson C, Hasan U, Yuspa SH, Trinchieri G. MyD88 and its divergent toll in carcinogenesis. Trends Immunol 34: 379-389, 2013.

39. Salcedo R, Worschech A, Cardone M, Jones Y, Gyulai Z, Dai RM, Wang E, Ma W, Haines D, O'hUigin C, Marincola FM, Trinchieri G. MyD88-mediated signaling prevents development of adenocarcinomas of the colon: role of interleukin 18. J Exp Med 207: 1625-1636, 2010.

40. Saleh M, Trinchieri G. Innate immune mechanisms of colitis and colitis-associated colorectal cancer. Nat Rev Immunol 11: 9-20, 2011.

41. Saunders SP, Barlow JL, Walsh CM, Bellsoi A, Smith P, McKenzie AN, Fallon PG. C-type lectin SIGN-R1 has a role in experimental colitis and responsiveness to lipopolysaccharide. J Immunol 184: 2627-2637, 2010.

42. Schwabe RF, Jobin C. The microbiome and cancer. Nat Rev Cancer 13: 800-812, 2013.

43. Terzic J, Grivennikov S, Karin E, Karin M. Inflammation and colon cancer. Gastroenterology 138: 2101-2114. e2105, 2010.

44. Thaker AI, Shaker A, Rao MS, Ciorba MA. Modeling colitis-associated cancer with azoxymethane (AOM) and dextran sulfate sodium (DSS). $J$ Vis $\operatorname{Exp}$ 67: 4100, 2012.

45. Valkov E, Stamp A, Dimaio F, Baker D, Verstak B, Roversi P, Kellie S, Sweet MJ, Mansell A, Gay NJ, Martin JL, Kobe B. Crystal structure of Toll-like receptor adaptor MAL/TIRAP reveals the molecular basis for signal transduction and disease protection. Proc Natl Acad Sci USA 108: 14879-14884, 2011.

46. Verstak B, Nagpal K, Bottomley SP, Golenbock DT, Hertzog PJ, Mansell A. MyD88 adapter-like (Mal)/TIRAP interaction with TRAF6 is critical for TLR2- and TLR4-mediated NF-kappaB proinflammatory responses. J Biol Chem 284: 24192-24203, 2009.

47. Wang EL, Qian ZR, Nakasono M, Tanahashi T, Yoshimoto K, Bando Y, Kudo E, Shimada M, Sano T. High expression of Toll-like receptor 4/myeloid differentiation factor 88 signals correlates with poor prognosis in colorectal cancer. Br J Cancer 102: 908-915, 2010.

48. Wang J, Ford HR, Grishin AV. NF-kappaB-mediated expression of MAPK phosphatase- 1 is an early step in desensitization to TLR ligands in enterocytes. Mucosal Immunol 3: 523-534, 2010.

49. Xavier RJ, Podolsky DK. Unravelling the pathogenesis of inflammatory bowel disease. Nature 448: 427-434, 2007.

50. Yamamoto M, Sato S, Hemmi H, Sanjo H, Uematsu S, Kaisho T, Hoshino K, Takeuchi O, Kobayashi M, Fujita T, Takeda K, Akira S. Essential role for TIRAP in activation of the signalling cascade shared by TLR2 and TLR4. Nature 420: 324-329, 2002. 